\title{
Recent advances in fish hatchery management
}

\author{
Ronald P. Phelps ${ }^{1}$
}

\author{
${ }^{1}$ Department of Fisheries and Allied Aquacultures - Auburn University, Auburn Alabama, USA.
}

\begin{abstract}
The advancement of aquaculture has often been bottlenecked because of the lack of seed, but once that bottleneck was overcome there was rapid growth. Recent examples of advances in hatchery technology leading to increased production are sea bream and Pangasius. Three areas contributing to the advancement of hatchery management are: brood stock management, induced spawning and larval feeding. Formulated diets have been developed for marine brood fish that are equal or better than the traditional raw fish diets. The importance of lipids and their composition in brood fish diets, particularly n-3 HUFAs has received much attention. The lipid composition of the brood diet is reflected in egg composition and egg quality. Protein quantity and quality in brood diets also impacts reproductive success and egg quality. The use of Gonadotropin-releasing hormone agonists (GnRHa) given as an injection or a slow release implant for induced spawning is becoming more widely used. The addition of dopamine antagonists with GnRHa may not be necessary to successfully induce spawn some species of fish. The use of GnRHa can advance the maturation of oocytes allowing such fish to be successfully induced spawned. Significant advances have been made in the development of formulated microdiets for larval fish. Such microdiets have been used successfully with young larvae reducing the need for live foods such as artemia. The quality of both live foods and formulated diets has been enriched with the use of fatty acids. Not only the quantity of n-3 HUFAs added to a diet impacts larval growth and survival but the ratios of specific n-3 HUFAs has an impact. Enrichment of live foods with amino acids can also improve larval fish growth and survival.
\end{abstract}

Key Words: aquaculture, broodfish nutrition, fish hatchery management, induced spawning, larval diets

\section{Avanços recentes em larvicultura}

RESUMO - A escassez de alevinos tem sido um dos principais pontos de estrangulamento para o avanço da aquicultura. No entanto, quando a produção de alevinos em quantidade e qualidade deixa de ser limitante, o setor produtivo normalmente apresenta rápido crescimento. Exemplos recentes de avanços em tecnologia de reprodução que resultaram no aumento da produção aquícola são os do pangasius (Pangasius sp.) e dourada (Sparus aurata). Dietas têm sido desenvolvidas para reprodutores de espécies marinhas com qualidade semelhante ou mesmo superior às tradicionais dietas à base de peixe. A composição lipídica, particularmente ômega-3 e ácidos graxos altamente insaturados "HUFAs", das dietas de reprodutores se reflete na composição e qualidade dos ovos. A qualidade da proteína e sua concentração na dieta também influenciam no sucesso reprodutivo e na qualidade dos ovos. A utilização de hôrmonios liberadores de gonadotrofinas (GnRHa) administrados por injeção ou como implantes de liberação lenta para a indução de desova tem sido amplamente utilizada. Nestas espécies o GnRHa estimula o avanço da maturação dos ovócitos fazendo com que a desova induzida ocorra com sucesso. Tem-se observado significantes avanços no desenvolvimento de microdietas elaboradas para larvas de peixes. Essas microdietas têm sido utilizadas com sucesso reduzindo a demanda das larvas por alimentos vivos como a artemia, e a qualidade de ambos alimentos tem sido melhorada com o uso de ácidos graxos. Não somente a quantidade de omega-3 HUFAs adicionada a uma dieta influência o crescimento de larvas, mas também a proporção dos ácidos graxos específicos. O enriquecimento de alimentos vivos com aminoácidos pode também melhorar o crescimento e a sobrevivência de larvas de peixes.

Palavras-chave: alimentos para larvas, aquicultura, desova induzida, manejo de larvicultura, nutrição de reprodutores

\section{Introduction}

Many times the advancement of aquaculture has been bottlenecked because of the lack of seed, but once that bottleneck was overcome there was rapid growth. Culture of Chinese carp is one of the oldest forms of aquaculture, but it was restricted to areas of China where seed could be collected from the wild and distributed. Its production remained restricted for thousands of years until the 1950s when induced spawning techniques were developed. This allowed these valuable aquaculture species to become available worldwide. The recent rapid growth of marine fish

Corresponding author: phelprp@auburn.edu 
culture has been due in part to being able to overcome the bottleneck of seed production. Gilthead sea bream is a highly valued fish throughout the Mediterranean, whose culture was limited until hatchery techniques were improved. In the 1960s and '70s, some of the initial research was conducted regarding the reproduction of this species. The fish could be reproduced successfully but larval survival was very low (approximately $1 \%$ ). Once advances in larval nutrition and other aspects of early life history were made, survival improved and a commercial industry rapidly developed. Production of sea bream was more than 120,000 MT in 2005.

The Asian catfishes of the genus Pangasius are another example of the rapid growth possible once hatchery techniques become established. In 2000 Viet Nam produced limited quantities of Pangasius for domestic markets and little for export but by 2009 Viet Nam was exporting 607,700 MT/yr (Josupeit, 2010). Research on artificial propagation of river catfish in Viet Nam began 1978 with the first fry obtained in 1979 (Trong et al., 2002). In 1998 there was one Pangasius hatchery in the Dong Thap province but by 2000 there were 50 hatcheries producing 250 million fingerlings. The increased availability of seed has been one of the primary factors allowing the currently levels of Pangasius culture.

To increase seed supply a number of factors have to be considered. In the following sections recent advances in fish hatchery management particularly in the areas of brood management, induced spawning and larval rearing will be reviewed.

\section{Brood management}

Significant advancements have been made in regard to developing brood diets to optimize successful reproduction. Mazorra et al. (2003) conducted a series of studies to determine if the trash fish-based diet traditionally used with halibut, Hippoglossus hippoglossus, broodstock could be replaced by a formulated pelleted feed and to investigate the effects of docosahexaenoic acid (DHA), eicosapentaenoic acid (EPA), and arachidonic acid (ARA) on halibut fecundity, blastomere morphology and fertilization and hatching rates. Two formulated broodstock feeds, one containing Krill meal and one supplemented with tuna orbital oil, which provided higher dietary levels of DHA and ARA), gave similar performances to that of fish fed a trash fish-based diet. In a second trial the spawning performance and egg quality of broodstock given two formulated diets containing different levels of ARA (1.8\% and $0.4 \%)$ were compared to the trash-fish diet. The formulated diet with the higher (1.8\%) level of ARA resulted in significantly higher fertilization rates and hatching rates (51.0 plus or minus $3.6 \%$ ) compared to those on the $0.4 \%$. Eggs selectively accumulated DHA, up to $30 \%$ of the total fatty acids. DHA/EPA and EPA/AA ratios of 2 and 4 in the eggs respectively were associated with improved egg and larval quality, similar to that achieved by fish maintained on the trash fish-based diets. In other marine species formulated diets have proven to be comparable to raw fish diets: mangrove red snapper, Lutjanus argentimaculatus, Emata \& Borlongan, 2003; and Japanese flounder Paralichthys olivaceus, Hondo et al. (2006).

The impact of brood diet has been shown for several freshwater species. Lane et al. (2006) evaluated the effect of dietary lipid and fatty acids on white bass, Morone chrysops, reproductive success. Four diets containing $45 \%$ crude protein and $15 \%$ lipid and graded levels of menhaden oil ( 0 , 25,75 , and $100 \%$ ) or corn oil were tested. The results showed that higher egg hatchability was associated with higher levels of n-3 HUFAs. The type of lipid and its concentration also affects channel catfish Ictalurus punctatus spawning success. Sink \& Lochmann (2008) evaluated poultry fat, (PF) or menhaden fish oil (FO) at concentration of 4 or $10 \%$ lipid in channel catfish broodstock diets. Diets with $10 \%$ fish oil had increased spawning success, fecundity, individual egg weight, eggs/spawn, total egg lipid concentration, hatching success, and fry survival compared to the diet with $4 \%$ fish oil. Although eggs from brooders given diets with either $10 \%$ poultry fat or menhaden fish differed in egg fatty acid composition there were no differences in hatching rates, fry survival, or fingerling production. They concluded that current methods of using growout diets with 28-32\% protein and 6-7\% lipid are suboptimal for channel catfish brood fish.

The effects of dietary protein and energy level on spawning performance of Nile tilapia broodstock and their eggs were studied by El-Sayed \& Kawanna (2008). Nine diets containing three protein (30, 35 and $40 \%$ ) and three energy (14.6, 16.7 and $18.8 \mathrm{MJ} \mathrm{GE} / \mathrm{kg}$ ) levels were evaluated. At the low protein level (30\%), time to first spawning was significantly longer than at 35 and $40 \%$ protein levels. It also increased as the protein-to-energy (P/E) ratio decreased. Spawning performance, including total number of spawnings/ tank, number of spawns/ female, absolute fecundity and average number of eggs/ spawn, were all significantly lower at 30\% CP than at higher protein levels. At decreasing P:E ratios there was a significant decrease in fish fecundity. The authors concluded that best spawning performance was achieved at $40 \%$ dietary protein 
and 16.7 MJ GE/kg, with a P/E ratio of $23.6 \mathrm{~g} / \mathrm{MJ}$. Bhujel et al. (2001) evaluated three commercial feeds for use with Nile tilapia brooders in a hapa-based spawning system. The feeds were a $5 \mathrm{~mm}, 25 \%$ protein pellet and a $3 \mathrm{~mm}, 30 \%$ protein pellet for catfish, and a 5-6 mm, 15.5\% protein pellet for herbivorous fishes. Seed production by brooders given the catfish feeds were similar. Females given the $25 \%$ and $30 \%$ protein feeds produced $27 \%$ and $30 \%$ more seed, respectively, than females fed the herbivorous diet. The number of seed/ gram of feed given was significantly higher for fish given the $30 \%$ protein feed, which resulted in the lowest seed production cost of the three feeds used.

\section{Induced spawning}

Induced spawning through hormone application has been a part of hatchery production since the pioneering work done in Brazil by Rudolho von Ihering in 1934 using fish pituitary (von Ihering, 1937). Fish pituitary continues to be widely used and its use refined. In addition a number of hormones have proven to be effective. Gonadotropinreleasing hormone agonists ( $\mathrm{GnRHa}$ ) particularly Lutenizing-Releasing Hormone(LH-RHa) has become widely used as an injection or a slow release implant.

The mode of GnRHa application was investigated by Fornies et al. (2001). Mature female sea bass (Dicentrarchus labrax) were treated with GnRHa-loaded microspheres, GnRHa-loaded implants, or given a single injection of GnRHa. Microspheres and implants induced multiple spawns/ female, whereas GnRHa-injected fish spawned only once. The authors concluded that GnRHa-loaded microspheres can induce multiple spawns in European sea bass, without a negative effect on egg quality. Determining proper dose rate using implants was studied by Ibarra-Castro \& Duncan (2007) working with recently caught wild spotted rose snapper (Lutjanus guttatus). They compared implants containing 0, 25, 50, 75 and 100 mug of GnRHa. The 75 mug implant-induced fish gave eggs with a significantly higher hatch rate. Number of floating eggs/ kg and number of hatching eggs/kg were correlated oocyte diameter and GnRHa dose. Ibarra-Castro \& Alvarez-Lajonchere (2009) developed an improved induced-spawning protocol for using GnRHa implants with spotted rose snapper (Lutjanus guttatus). A nomograph was developed to calculate the required GnRHa implant dose, taking into account the origin of the female (wild vs. captive), the initial mean oocyte diameter, and body weight. The effective GnRHa dose was greater in wild than captive females and in both cases, inversely related to mean oocyte diameter.

The fish hypothalamus is the organ that would under favorable environmental conditions naturally produce
GnRH, stimulating the pituitary to produce gonadotropins. Under stressful conditions the hypothalamus produce dopamines that inhibit the pituitary from producing gonadotropins. To counter this effect several forms of dopamine antagonists have been given in combination with GnRHa for induced spawning. Nayak et al. (2001) evaluated the efficacy of (LH-RHa), the dopamine antagonist pimozide (PIM) and a commercial spawning product (ovaprim, containing both GnRHa and a dopamine antagonist) on oocyte maturation, ovulation and spawning of the catfish Heteropneustes fossilis Both LHRHa and pimozide when given alone failed to induce ovulation, but both drugs did advance oocyte maturation. In combination, LHRHa and PIM (0.05 mg +5 mg/g/body weight respectively) resulted in a high rate of ovulation, hatching and high yield of normal larvae. A single dose $(0.6-0.8 \mathrm{ml} / \mathrm{kg}$ ) of ovaprim injected gave similar rates of hatchability and normal larvae. Van Eenennaam et al. (2008) compared injections of GnRHa along and GnRHa plus the dopamine antagonist domperidone to induce ovulation in green sturgeon Acipenser medirostris. All broodfish ovulated or spermiated in all hormonal treatments, and the best treatment was GnRHa injected alone in a single dose of $10 \mathrm{mg} / \mathrm{kg}$ for males or in a 1- $\mathrm{mg} / \mathrm{kg}$ priming dose and a $19-\mathrm{mg} / \mathrm{kg}$ resolving dose for females. Domperidone was not required for successful ovulation and appeared to reduce the adhesion of ovulated eggs.

GnRHa has been used to advance egg maturation and induce ovulation when given as an implant or via injection, often in combination with other drugs. Prat et al. (2001) treated European sea bass females in late vitellogenesis with two i.p. injections of GnRHa alone (5 and $20 \mathrm{mg} / \mathrm{kg}$ ) given $12 \mathrm{~h}$ apart, or combined with pimozide (PIM) (10 $\mathrm{mg} / \mathrm{kg}$ ) either in the first or second injection. Administration of GnRHa alone or combined with PIM accelerated the final oocyte maturation and induced spawning. The number of eggs spawned was highest in the group that received GnRHa alone and lowest in the group that received PIM in the second injection. The authors concluded that the use of PIM does not improve the GnRHa treatment and the use of GnRHa alone during the last stages of vitellogenesis is enough to induce final oocyte maturation in European sea bass. Yeager (2006) found that LH-RHa given in combination with HCG could advance oocyte maturation and induce spawn female striped bass Morone saxatilis that otherwise would be considered insufficiently mature for induced spawning. Females with eggs in early stages of development were successfully spawned (18 of 19) after being given a priming injection of 
LH-RHa followed by a resolving injection of human chorionic gonadotropin (HCG). This procedure, which differs from the traditional spawning method of HCG injection, can increase production by using broodfish that once would have been considered to be ineligible because they contained eggs in early developmental stages.

Several products containing GnRHa and a dopamine antagonist are now commercially available. Oviprim has been successfully injected into more than 15 fish species in the last 20 years. Dagin, another commercial product, combines an analog of sGnRH (10 mg/kg), with a dopamine antagonist, metoclopramide (20 mg/kg). Yaron et al. (2009) tested common carp pituitary and Dagin to induce common carp reproduction. The spawning ratio and embryo viability were similar, but the latency between injection and ovulation was considerably longer and more variable in Dagin-treated than in CCPE-treated carp. They recommended the use of carp pituitary at the beginning and end of the spawning season when the LH content in the pituitary is low, and Dagin in mid-season. A commercial induce-spawning agent, (Ovatide), was evaluated by Marimuthu et al. (2007). Ovatide, which is a mixture of a synthetic GnRH analog and a dopamine antagonist, was used to induce spawn striped snakehead, Channa striatus. The authors found that a dose of $0.4 \mathrm{~mL} / \mathrm{kg}$ was effective for inducing spawning. Gonazon, which contains the GnRH analog, azagly-nafarelin but not a dopamine antagonist, is approved in EU for salmonides.

As the availability of commercial sources of GnRHa become more widespread, its use will become even more common. Unless other sources of fish pituitary become available, the use of pituitary may reach a threshold and may not be cost-competitive with synthetic GnRH products. Likewise, the use of HCG may lose market-share as costs of an effective dose to induce ovulation is often less with GnRHa than HCG. Hatchery managers should anticipate further refinement in the use of GnRHa and its mode of application with many new species being induced to spawn with it.

\section{Larval feeding}

In the hatchery-rearing of some fish species, the transition from one type of food to another can be a challenge. This period of transition often referred to as a period of co-feeding or weaning may be between two types of live feed or from a live feed to an inert formulated diet. Shields et al. (2003) studied the effects of diet transition on larval Atlantic cod, Gadus morhua. Larvae were transferred from rotifers, Brachionus plicatilis, to Artemia nauplii on either day 5, 15 or 25 post-hatch (ph). Rotifers were progressively withdrawn over a 5-day period. Larvae transferred to Artemia from day 5 ph suffered a high incidence of swimbladder over-inflation and high mortality during metamorphosis. Highest mean survival rates to day $40 \mathrm{ph}(18.1 \%)$ and lowest mortality was for the larvae that remained on rotifers past day 25 . The authors recommend that intensively reared Atlantic cod should continue to receive rotifers until completion of metamorphosis.

How to reduce the use of live feeds by weaning the larvae to formulated diets earlier in the life history has been an issue. Significant improvements in formulated diets for larval fish have occurred in regard to feed sizes, palatability and nutrient quality. Several commercial brands of microdiets are now available for larval fish. Artemia (brine shrimp) are a widely used live feed for many fish larvae, and can be a significant part of the cost of fry production. Callan et al. (2003) evaluated procedures for the early weaning of cod (Gadus morhua) larvae to reduce artemia usage by supplementation with a microdiet. As long as artemia were $25 \%$ or more of the diet there was no effect on length, dry weight, specific growth rate or survival when co-feeding a microparticulate diet. They concluded that when Artemia prices are high (US\$50/kg), significant savings are possible by co-feeding marine larval fish with microdiets. Curnow et al. (2006) evaluated the use of two commercial feeds as well as rotifers and artemia for feeding of barramundi Lates calcarifer. Co-feeding rotifers and a microdiet (Gemma Micro) allowed complete replacement of artemia. Significantly better growth and similar larvae survival was achieved compared to co-feeding rotifers, Artemia and another microdiet (Proton). By including artemia in the protocol with Gemma Micro survival was significantly improved, but growth to $28 \mathrm{dph}$ was inhibited. Larval growth and survival positively correlated with the number of days that rotifers were fed in those protocols that did not receive artemia. The best protocol for rearing barramundi larvae consisted of feeding enriched rotifers from first feeding until $5 \mathrm{~mm}$ standard length (SL), along with supplemental levels of enriched artemia from $5 \mathrm{~mm}$, to post metamorphosis at $12 \mathrm{~mm}$. Co-feeding a microdiet (i.e. Gemma Micro) should start when the larvae reach $5 \mathrm{~mm}$.

The success of co-feeding and weaning to a microdiet varies with the species, the weaning protocol and the type of formulated diet used. The weaning of tongue sole larvae Cynoglossus semilaev, was investigated by Chang et al. (2006). They compared use of rotifers and artemia to a cofeeding where a microdiet was added starting at 6-d posthatch. Co-feeding a microdiet and live prey (rotifers and Artemia) allowed larvae to complete metamorphosis and 
achieve similar specific growth rate and survival as that of larvae fed on live feed alone. The authors concluded that weaning $C$. semilaev from early development is feasible and co-feeding improves larval growth and survival. The weaning of fat snook (Centropomus parallelus Poey 1864) from artemia to a formulated feed was evaluated by Alves et al. (2006) beginning with 30-d post-hatch (DPH) larvae. The length of the co-feeding period affected the growth but not survival. Larval survival (over 91\%) was not significantly affected by treatment. Larvae were successfully weaned by $35 \mathrm{DPH}$, but those weaned by 40 DPH displayed higher growth rates and were significantly larger by the end of the experiment. Muesche \& Bengtson (2003) discussed how the transition from live feed to formulated diets, can result in cannibalism as some fish adapt to the new diet and grow while others do not adapt. They evaluated several management protocols to reduce growth variability and increase survival of summer flounder, Paralichthys dentatus. Time of weaning to a dry commercial pellet at 2, 4, or 6 wk post-metamorphosis resulted in fish weaned at $6 \mathrm{wk}$ post-metamorphosis had the smallest mean lengths, but the least variability in growth and the highest survival. Alternating feedings between artemia and a dry feed or co-feeding both at the same time resulted in no significant differences in survival or growth, however, the fish given artemia and dry diet simultaneously had the lowest variability in growth.

Much effort has been placed on improving the quality of both live foods and formulated diets for larval fish by better understanding of the nutrient requirements of larval fish. Enrichment of live foods has been a major area of emphasis. Artemia can be low in several fatty acids and various products and protocols have been investigated to improve artemia nutrient quality. Rotifers, a commonly given first food, are often enriched in an attempt to improve their nutrient quality. There are a number of commercial products are now available for fatty acid enrichment of live foods. An issue is what is an appropriate concentration of a specific fatty acid and how it interacts with other fatty acids. The effect of artemia enrichment with 22:6n-3 (docosahexaenoic acid, DHA) on growth and survival of striped trumpeter Latris lineata during metamorphosis and the artemia-feeding period (16-36 days posthatch, dph) was investigated by Bransden et al. (2005). They compared five concentrations of DHA while holding the concentration of arachidonic acid, (ARA) constant. They found that the length and dry weight of larvae at the end of the experiment were directly related to dietary DHA, Survival was not influenced by dietary DHA. Sato \&
Takeuchi (2009) studied the DHA requirement of larval brown sole Pleuronectes herzensteini. One-day-old larvae were fed rotifers Brachionus rotundiformis enriched with four levels of DHA. Twenty-day-old larvae were fed Artemia nauplii enriched with four levels of DHA for 27 days. The fatty acid profile of the larvae reflected the fatty acid composition of their diet in both studies. In the rotifer trial, larval survival increased as DHA level in rotifers increased from 0 to $0.6 \%$ (dry weight), but decreased as the rate increased from 0.6 to $3.3 \%$. In the artemia trial, larval survival rate improved as DHA content of artemia but did plateaued at 1.4 to $2.8 \%$ DHA. Van Anholt et al. (2004) found that when artemia were enriched with arachidonic acid (ARA) at 1.5 and $7.5 \mathrm{mg}$ ARA/g dwt, the ARA concentration altered the stress response of gilthead seabream (Sparus aurata) larvae. Feeding the high ARA artemia strongly reduced the cortisol response after air exposure of both 28 and 50 DPH larvae. The low ARA fed larvae responded to the salinity decrease with an initial increase in cortisol followed by a gradual decline below basal levels, whereas the high ARA larvae responded with a drop followed by a return to basal levels.

Amino acids are another important component of the diet of rapidly developing larvae providing the building blocks for protein synthesis, and are important energy substrates. Aragao et al. (2004) investigated the enrichment of rotifers and artemia with various sources of amino acids. Rotifers and Artemia were enriched for $24 \mathrm{~h}$ in microalgae, in commercial diets, or starved for $24 \mathrm{~h}$. The free AA (FAA) quantity and quality in both rotifers and Artemia metanauplii was strongly affected by the enrichment used. The relative FAA content was significantly higher in rotifers and Artemia enriched with microalgae than in the ones enriched with commercial products. Differences regarding the FAA quantity and quality were also found between rotifers and Artemia. With the exception of the starved preys, a higher relative FAA content was found in rotifers than in Artemia metanauplii and while the FAA pool of the rotifers was dominated by alanine, taurine was the dominant AA in the FAA pool of artemia. Aragao et al. (2007) discussed how manipulation of the amino acid composition of microencapsulated diets is more feasible than manipulating live feed composition. They investigated the effect of amino acid supplementation on growth and survival of gilthead seabream (Sparus aurata) larvae. Larvae were given either artemia or experimental microencapsulated diets supplemented with essential amino acids, or 
supplemented with non-essential amino acids. Larval survival was similar for those fed the essential amino acid diet (75\%) or artemia (87\%), but was significantly lower in larvae fed the non-essential amino acid supplemented diet (52\%). Final dry weight of larvae given either formulated diet was less than those given artemia. The authors concluded that dietary supplementation with essential amino acids resulted in a more balanced dietary amino acid profile, which significantly increased survival but further studies introducing microdiets earlier in the development seem necessary in order to optimize growth.

As greater understanding of the nutrient requirements of larval fish are gained and weaning protocols are improved, formulated diets will become more widely used and used earlier in the life history for many fish.

Recent advances in hatchery management have resulted in a much better control of critical life stages of fish. These advances will continue until the science of aquaculture is on a level with that of the other animal sciences.

\section{Conclusions}

The hatchery phase is often the aspect that limits aquaculture expansion. Induced spawning techniques have improved for a number of species administering gonadotropin releasing hormones via injection or implantation. Advances have been made in broodstock diets, specifically in the use of fatty acids to improve egg quality to equal that of brooders given natural diets. Improvements in formulated diets for larval fish have reduced the dependence on live foods at earlier and earlier stages in the life history. Co-feeding during the larval stages helps to reduce the need for live foods and facilitates the transition to formulated diets. Advances will continue until the science of aquaculture is on a level with that of the other animal sciences.

\section{References}

ALVES, T.T.; CERQUEIRA, V.R.; BROWN, J.A. et al. Early weaning of fat snook (Centropomus parallelus Poey 1864) larvae. Aquaculture, v.253, n.1-4, p.334-342, 2006.

ARAGAO, C.; CONCEICAO, L.E.C.; LACUISSE, M. et al. et al. Do dietary amino acid profiles affect performance of larval gilthead seabream? Aquatic Living Resources, v.20, n.2, p.155-161, 2007.

ARAGAO, C.; CONCEICAO, L.E.; DINIS, M.T. et al. Amino acid pools of rotifers and Artemia under different conditions: nutritional implications for fish larvae. Aquaculture, v.234, p.429-445, 2004.

BHUJEL, R.C.; YAKUPITIYAGE, A.; TURNER, W.A. et al. Selection of a commercial feed for Nile tilapia (Oreochromis niloticus) broodfish breeding in a hapa-in-pond system. Aquaculture, v.194, n.3-4, p.303-314, 2001.
BRANSDEN, M.P.; BATTAGLENE, S.C.; MOREHEAD, D.T. et al. Effect of dietary 22:6n-3 on growth, survival and tissue fatty acid profile of striped trumpeter (Latris lineata) larvae fed enriched Artemia. Aquaculture, v.243, n.1-4, p.331-344. 2005.

CALLAN, C.; JORDAAN, A.; KLING, L.J. et al. Reducing Artemia use in the culture of Atlantic cod (Gadus morhua). Aquaculture, v. 219, p. 585-595, 2003.

CURNOW, J.; KING, J.; BOSMANS, J. et al. The effect of reduced Artemia and rotifer use facilitated by a new microdiet in the rearing of barramundi Lates calcarifer $(\mathrm{BLOCH})$ larvae. Aquaculture, v.257, n.1-4, p.204-213, 2006.

CHANG, Q.; LIANG, M.Q.; WANG, J.L. et al. Influence of larval co-feeding with live and inert diets on weaning the tongue sole Cynoglossus semilaevis. Aquaculture, v.12, n.2, p.135-139, 2006.

EL-SAYED, A.F.M.; KAWANNA, M. Effects of dietary protein and energy levels on spawning performance of Nile tilapia (Oreochromis niloticus) broodstock in a recycling system. Aquaculture, v.280, p.179-184, 2008.

EMATA, A.C.; BORLONGAN, I.G. A practical broodstock diet for the mangrove red snapper, Lutjanus argentimaculatus. Aquaculture, v.225, p.83-88, 2003.

FORNIES, M.A.; MANANOS, E.; CARRILLO, M. et al. Spawning induction of individual European sea bass females (Dicentrarchus labrax) using different GnRHa-delivery systems. Aquaculture, v. 202, p.221-234, 2001.

HONDO, Y.; MURAKAMI, N.; MUSHIAKE, K. et al. Broodstock management and egg collection from reared wild-broodstock of Japanese flounder Paralichthys olivaceus fed commercial extruded pellets. Nippon Suisan Gakkaishi, v.72, n.5, p.873879, 2006.

IBARRA-CASTRO, L.; DUNCAN, N.J. GnRHa-induced spawning of wild-caught spotted rose snapper Lutjanus guttatus. Aquaculture, v.272, p.737-746, 2007.

IBARRA-CASTRO, L.; ALVAREZ-LAJONCHERE, L. Improved induced-spawning protocol for the spotted rose snapper (Lutjanus guttatus). Israeli Journal of Aquaculture, v.61, p.121-133, 2009.

JOSUPEIT, H. [2010]. Pangasius market report. FAO globefish. Available in: <http://www.globefish.org>

LANE, R.L.; KOHLER, C.C. Source effects of dietary lipid and fatty acids on white bass reproductive performance, egg hatchability, and overall quality of progeny. North American Journal of Aquaculture, v.68, p.141-150, 2006.

MARIMUTHU, K.; KUMAR, D; HANIFFA, M.A. Induced spawning of striped snakehead. Channa striatus, using ovatide. Journal of Applied Aquaculture, v.19, p.95-103, 2007.

MAZORRA, C.; BRUCE, M.; BELL, J.G. et al. Dietary lipid enhancement of broodstock reproductive performance and egg and larval quality in Atlantic halibut (Hippoglossus hippoglossus). Aquaculture, v. 227, p.21-33, 2003.

MUESCHE, J.; BENGTSON, D.A. Effects of weaning strategies on growth and survival of juvenile summer flounder, Paralichthys dentatus. Journal of Shellfish Research, v.22, p.297, 2003.

MYLONAS, C.C.; MAGNUS, Y.; GISSIS, A. et al. Application of controlled-release, GnRHa-delivery systems in commercial production of white bass $\mathrm{x}$ striped bass hybrids (sunshine bass), using captive broodstocks. Aquaculture, v.140, n.3, p.265280, 1996.

NAYAK, P.K.; MISHRA, T.K.; SINGH, B.N. et al. Induced maturation and ovulation in Heteropneustes fossilis by using LHRHa, pimozide and ovaprim for production of quality eggs and larvae. Indian Journal of Fisheries, v.48, p.269-275, 2001.

PRAT, F.; ZANUY, S.; CARRILLO, M. Effect of gonadotropinreleasing hormone analogue (GnRHa) and pimozide on plasma levels of sex steroids and ovarian development in sea bass (Dicentrarchus labrax L.) Aquaculture, v.198, p.325-338, 2001. 
SATO, N.; TAKEUCHI, T. Docosahexaenoic acid (DHA) requirement of larval brown sole Pleuronectes herzensteini. Nippon Suisan Gakkaishi, v.75, n.1, p.28-37. 2009.

SHIELDS, R.J.; IRWIN, S.; SMITH, P.L. et al. Effects of diet transition regimen on survival, growth and lipid composition of intensively reared Atlantic cod, Gadus morhua, larvae. Aquaculture International, v.11, p.119-130, 2003.

SINK, T.D.; LOCHMANN, R.T. Effects of dietary lipid source and concentration on channel catfish (Ictalurus punctatus) egg biochemical composition, egg and fry production, and egg and fry quality. Aquaculture, v. 283, n.1-4, p.68-76.

TRONG, T.Q.; HAO, N.V.; GRIFFITHS, D. Status of Pangasiid aquaculture in Viet Nam. Phnom Penh: Mekong River Commission, 2002. 16p. (MRC Technical Paper, 2).

VAN ANHOLT, R.D.; KOVEN, W.M.; LUTZKY, S.; WENDELAAR BONGA, S.E. Dietary supplementation with arachidonic acid alters the stress response of gilthead seabream (Sparus aurata) larvae. Aquaculture, v.238, n.1-4, p.369-383. 2004.

VAN EENENNAAM, J.P.; LINARES-CASENAVE, J.R; MUGUET, J.-B. et al. Induced spawning, artificial fertilization, and egg incubation techniques for green sturgeon. North American Journal of Aquaculture, v.70, p.434-445, 2008.

VON IHERING, R. A method for inducing fish to spawn. Progressive Fish Culturist, v.34, p.15-16, 1937.

YARON, Z.; BOGOMOLNAYA, A.; DRORI, S. et al. Spawning induction in the carp: past experience and future prospects - a review. The Israeli Journal of Aquaculture, v.61, n.1, p.526, 2009.

YEAGER, D.M. Use of luteinizing hormone releasing hormone analog and human chorionic gonadotropin to spawn early-eggstage striped bass. North American Journal of Aquaculture, v.68, p.287-290, 2006. 